\title{
Weed seeds on clothing: A global review
}

This manuscript has been published in the Journal of Environmental Management and can be cited as:

Ansong, M., \& Pickering, C. (2014). Weed seeds on clothing: a global review. J Environ Manage, 144(0), 203-211. doi: http://dx.doi.org/10.1016/j.jenvman.2014.05.026

http://www.sciencedirect.com/science/article/pii/S0301479714002680

Michael Ansong*, Catherine Pickering

Environmental Futures Centre, Griffith University, Gold Coast, Queensland, 4222, Australia; *Author for correspondence. Phone +61 7 55528290, fax: 61755528067.

E-mail: michael.ansong@griffithuni.edu.au

\section{Summary}

Weeds are a major threat to biodiversity including in areas of high conservation value. Unfortunately, people may be unintentionally introducing and dispersing weed seeds on their clothing when they visit these areas. To inform the management of these areas, we conducted a systematic quantitative literature review to determine the diversity and characteristics of species with seeds that can attach and be dispersed from clothing. Across 21 studies identified from systematic literature searches on this topic, seeds from 449 species have been recorded on clothing, more than double the diversity found in a previous review. Nearly all of them (391 species) are listed weeds in one or more countries, with 58 classified as internationally-recognised environmental weeds. When our database was compared with weed lists from different countries and continents we found that clothing can carry the seeds of important regional weeds. A total of 287 of the species are listed as aliens in one or more countries in Europe, 156 are invasive species/noxious weeds in North America, 211 are naturalized alien plants in Australia, 97 are alien species in India, 33 are invasive species in China and 5 are declared weeds/invaders in South Africa. Seeds on the clothing of hikers can be carried to an average distance of $13 \mathrm{~km}$, and where people travel in cars, trains, planes and boats, the seeds on their clothing can be carried much further. Factors that affect this type of seed dispersal include the type of clothing, the type of material the clothing is made from, the number and location of the seeds on plants, and seed traits such as adhesive and attachment structures. With increasing use of protected areas by tourists, including in remote regions, popular protected areas may be at great risk of biological invasions by weeds with seeds carried on clothing.

Keywords: Human-mediated dispersal, biological invasion, long distance dispersal, invasive species, tourism impacts 


\section{Introduction}

Weeds are a major threat to biodiversity globally including in protected areas (Williams and West, 2000; Weber, 2003; Groves et al., 2005; Pickering and Hill, 2007; Pyšek and Richardson, 2010; Williams et al., 2010; Vilà et al., 2011; Stohlgren et al., 2013). They often have traits that make them more competitive than native plants, including high levels of seed production, fast growth rates, the ability to grow under a wide range of environmental conditions and tolerance of anthropogenic disturbance (Weber, 2003; Groves et al., 2005; Pauchard et al., 2009). These traits, along with possible reduced predation in new habitats, can result in weeds replacing native plants and altering biodiversity (Csurhes and Edwards, 1998; Williams and West, 2000; Groves et al., 2005; Pyšek and Richardson, 2010).

Weeds in protected areas can have important economic impacts, including increased management costs and reductions in the ecosystem services provided by the protected area (Williams and West, 2000; Sinden et al., 2004; Williams et al., 2010; McDougall et al., 2011; Stohlgren et al., 2013). For instance, the total expenditure on controlling weeds in natural environments in 2001-02 in Australia was estimated at approximately \$AU19.6 M of which 43\% was used for weed control in protected areas (Sinden et al., 2004). Ecosystem services degraded by weed invasions include reduced water quality and flow along rivers, changes to fire regimes due to invasions by more flammable species, and changes to soil conditions due to weeds altering soil chemistry and biota (Csurhes and Edwards, 1998; Weber, 2003; Groves et al., 2005)

Dispersal is a critical stage for biological invasions, including the introduction of weed seeds into protected areas. Deliberate introductions of weeds can occur when they are used in gardens around visitor facilities and in rehabilitation programs in protected areas (Johnston and Pickering, 2001; McDougall et al., 2011). Visitors to protected areas can also act as unintentional dispersal vectors for weed seeds. They can accidentally carry and disperse seeds on their clothing, vehicles, animals (horses, mules etc) and in animal feed (Mount and Pickering, 2009; Pickering and Mount, 2010; Chown et al., 2012; Taylor et al., 2012; Ware et al., 2012). This includes a wide diversity of weeds, with seeds from 599 weed species collected from vehicles (Ansong and Pickering, 2013a), and seeds from 246 weed species germinated from horse dung (Ansong and Pickering, 2013b).

The risk of visitors to protected areas dispersing weed seeds is growing, with increasing movement of nature based tourists between different habitats on local, national, regional, and 
transcontinental scales (Worboys et al., 2005; Pickering and Mount, 2010; Newsome et al., 2012). Protected areas in some regions experience high levels of visitation with around 1.4 million people visiting terrestrial reserves in Australia each year (Director of National Parks, 2011), over 280 million visits to protected areas in the USA in 2012 (Street, 2013), and over 4.9 million visitors to South African national parks between 2012 and 2013 (South African National Parks, 2013). Even remote protected areas can experience high levels of visitation with over 500,000 tourists for instance visiting Antarctica from September 2012 to July 2013 (International Association of Antarctica Tour Operators, 2013).

Many visitors to protected areas may carry weed seeds on their clothing (Pickering and Mount, 2010). For example $73 \%$ of visitors to a national park in Australia carried seeds on their clothing, and modelling indicates that they could collectively carry millions of seeds each year (Pickering et al. 2011). Visitors to even more remote protected areas can still carry large amounts of seeds (Chown et al., 2012; Ware et al., 2012). Surprisingly, some visitors may even deliberately spread weed seeds, with two visitors found deliberately dispersing Barley (Hordeum vulgare) seeds as they hiked on Deception Island, off the Antarctic Peninsula (Darby, 2012).

While it is clear that people can unintentionally carry weed seeds on clothing, what is less clear is which weeds can be dispersed by this means, and where are they a problem? A previous review of seeds from vehicles, clothing and/or in the dung of horses used for recreational activities identified over 700 species dispersed by these vectors (Pickering and Mount, 2010). To inform the management of protected areas, we undertook a global review of studies on clothing as a type of anthropochory to better assess the potential for weed dispersal via clothing. This included updating and expanding an existing database (Pickering and Mount, 2010). Our aims were to determine: (1) which species have seeds that can be dispersed from clothing? (2) How many of these species are weeds globally, in Europe, Australia, North America, Asia, and in Africa? (3) How many seeds can be dispersed from clothing and how many could be viable? (4) How far can the seeds be dispersed by hikers? (5) Are some species common among studies? (6) What plant and seed traits influence attachment and detachment of seeds on clothing? (7) What characteristics of clothing influence seed attachment and detachment? and, (8) what are the effects of environmental conditions on seed attachment and detachment from clothing?

\section{Methods}




\subsection{Identifying studies}

A systematic review designed to identify studies of seeds dispersed on clothing was undertaken. As a first step, information on the diversity of species with seeds on clothing was extracted from an existing, more general review of weeds dispersed by tourists on clothing, vehicles, and in dung and furs of horses and donkeys (Pickering and Mount, 2010). We retained 11 studies of seeds on clothing to which we added data from 10 new studies located using searches of electronic databases from April 2012 to June 2013. This involved conducting a systematic search of papers published in English from both the primary literature (peer-reviewed) and project reports using ScienceDirect, Web of Science, Scopus, Google Scholar, and Google. A search string using a combination of the following keywords was used: man, human, tourists, visitors, boots, footwear, shoes, cloth*, hik*, weeds, seeds, diaspores, spread, transport* and disper*. We used different combinations of search terms based on the requirements or limitations of each database. The search strategy for ScienceDirect, for example, was (man OR human OR tourists OR visitors OR boots OR footwear OR shoes OR cloth* OR hik*) AND (weeds OR seeds OR Alien species OR Invasive species OR non-native OR diaspores) AND (Spread OR Transport* OR Disper*). The references cited by potentially relevant papers, were reviewed to locate additional potential studies, but only if they were published in English.

Initially, 92 potentially relevant studies were identified. To ensure that we only selected those studies that were related to the topic, we first screened the studies obtained from the database searches by reading their titles and abstracts, and then excluded those that did not mention: (1) clothing as dispersal vectors, or (2) dispersal, or spread, or transportation, or (3) dispersal of plants, or weeds or alien species or invasive species. We then obtained the full text for the studies that passed this initial screening to review them in detail. In the second screening, studies were excluded if they did not generate empirical data or reported on seeds dispersed by vectors other than clothing. Those that were not empirical, but based on speculation were excluded.

Twenty-one studies fitting the criteria listed were included in the database.. Published between 1918 and 2013, these studies included research from Europe (six studies), Australia (eight studies) and New Zealand (three studies) (Table 1). The studies had one of three research designs: (1) opportunistic sampling studies, where seeds were collected without any experimental design but as part of other activities (nine studies), (2) manipulative 
experimental studies that involved the use of controls, often randomization in the allocation of treatments and statistical analyses of the results (seven studies), and (3) natural experiments that involved some sort of experimental design but no, or limited, statistical testing (five studies) (Table 1).

\section{Table 1 near here}

Two datasets from one of the authors of this review were included in the global database (Table 1). Both quantified the amount and type of seeds collected and dispersal distances on human clothing. The first dataset is from seeds collected on socks, shoes and trousers when walking in roadside and natural vegetation in Kosciuszko National Park in temperate southeastern Australia. The second is for seeds from socks and shoes worn on a walking track linking two national parks on the east coast of Australia in the subtropics (Table 1). Authors of one of the published studies (McNeill et al., 2011), kindly provided more complete species lists than were included in the original paper.

\subsection{Data extraction}

From each of the studies we also obtained the following information: the name of author(s), publication year, type of clothing sampled, geographical location of the study (continent and country), method used to identify species (germination or direct identification), whether the study was conducted in a protected area or not, number of taxa listed in the study and the number of species we could include in the database (e.g. full species name). For all of the species identified, information was added to the database including binomial name, common name, synonyms, family, growth form and life span. These were sourced from PlantNET (Royal Botanic Gardens and Domain Trust, 2012), Global Compendium of Weeds (Randall, 2012), United States Department of Agriculture (GRIN Taxonomy for Plants, 2012) and Invasive Plants of the World (Weber, 2003). Plant nomenclature conforms to PlantNET (Royal Botanic Gardens and Domain Trust, 2012) and United States Department of Agriculture (GRIN Taxonomy for Plants, 2012). The dataset only included presence/absence data for species due to variation in the methods used, duration and location of study and measurements taken among the studies. Only data at the level of species was included, not genera, and only if the scientific name was included (e.g. not morphotaxa). The number of species on different items of clothing could not be compared as not all studies presented data at that level of detail. The total number and characteristics of the species recorded on clothing were summarized descriptively and presented using simple tables. 


\subsection{Weed status of species}

We assessed the weed status of each species in the database using a range of weed lists for different regions (Europe, North America, Australia, Asia and Africa) and scales (global, regional and country). For example, to determine if a species was considered a weed somewhere in the world, data from the Global Compendium of Weeds was used (Randall, 2012). To determine if the species were international environmental weeds, we used the list of 400 species from Invasive Plant Species of the World: A Reference Guide to Environmental Weeds which lists the top 400 international environmental weeds (Weber, 2003).

To assess how many species of weeds in Europe could be dispersed on clothing, we used the European Alien Species Database of the Delivering Alien Invasive Species Inventories for Europe (DAISIE) (DAISIE, 2008). The DAISIE database lists alien species that are mainly invasive or naturalized in the 27 European Union member states and other European states (Lambdon et al., 2008; Hulme et al., 2009). It included 5,970 species when accessed in January 2013, including the 150 most widespread alien plant species in Europe (Lambdon et al., 2008). We also assessed the invasive status of the species, according to the information on alien and invasive plant species in North and Central Europe provided by the European Network on Invasive Alien Species (NOBANIS) (NOBANIS, 2013). To see if these dispersal mechanisms are common in the weed flora of a specific country in Europe we used the catalogue of invasive species for Czech Republic (Pyšek et al., 2012), which comprises 1,454 alien taxa, of which 61 classified as invasive (Pyšek et al., 2012).

Data on the weed status of the species in the database in Australia were obtained from The List of the Introduced Flora of Australia and their Weed Status (Randall, 2007). This publication includes 2,739 species of weeds that are naturalised in Australia. We also used the database from the Australian Weeds Committee that provides details of 429 plant species declared noxious weeds by a state or territory government in Australia (Australian Weeds Committee, 2012a) and 32 Weeds of National Significance, that are the most problematic weed species as determined by the Australian Government (Australian Weeds Committee, 2012b).

To assess how many weed species in North America could be dispersed on clothing, we used the list of plant species that are considered invasive/noxious in North America by the joint project of the Centre for Invasive Species and Ecosystem Health from the University of 
Georgia, and United States Department of Agriculture (USDA) Animal and Plant Health Inspection Service (Invasive.org, 2010). The list has a total of 1,596 species (Invasive.org, 2010). We also used the United States Department of Agriculture (USDA) list of 112 plant species declared federal noxious weeds in the United States (USDA, 2013).

A single comprehensive list of invasive species for Asia was difficult to obtain, so we focused on weed lists for the two countries in the region with the largest human populations: India and China. For India, we used a list of 1,599 species from 161 families classified as alien plant species, of which 225 are declared invasive in India (Khuroo et al., 2012). A list of 265 invasive plant species was used for China (Xu et al., 2012). The species lists from both of these studies (Khuroo et al., 2012; Xu et al., 2012) were compiled from relevant publications, databases and field observations.

As a comprehensive database of weed species could not be obtained for the whole of Africa, we used a weed list for South Africa, which has one of the largest human populations on the continent. The list of 198 species of weeds/invasive plants listed in Regulation 15 of The Conservation of Agricultural Resources Act, No. 43 of 1983 of South Africa was used. The Act divides the weeds/invaders species into three categories with Category I the most problematic (South Africa Government Gazette, 2001).

\subsection{Statistical analysis}

To determine if species with specific growth forms and life spans were more likely to be collected on clothing we used the Chi-square goodness of fit tests. The Chi-square test for independence was also used to determine if there was a significant association between the growth form and life spans of the species collected on clothing. The categories annual, biennial and those species both annual and biennial were combined and termed as 'annual/biennial' while those with mixed or intermediate life spans such as biennial/perennial and annual/perennial were combined to form a category called 'mixed'. Perennial species were retained as perennials.

\section{Results}

3.1 Which species have seeds that can be dispersed from clothing? 
From the 21 studies, seeds of 449 species were collected from clothing (Table 2, Supplementary material 1), with an average of 21 species per study and a range of 1 to 191 species among the different studies (Table 1). Seeds were collected from a variety of clothing including from trousers, shirts, socks, laces and footwear. Most of the seeds were collected by brushing, vacuuming seeds and/or hand removal. Species in 16 studies were directly identified from the seeds using taxonomic guides and seed reference collections, while three studies identified species from seedlings germinated from glasshouse/laboratory (Table 1).

\section{Table 2 near here}

The species were from 57 families of plants, however, five families accounted for $55 \%$ of the diversity, with 124 species from the Poaceae, 70 from Asteraceae, 30 from Cyperaceae, 26 from Fabaceae, and 23 from Caryophyllaceae (Supplementary material 1, Figure 1). There was far greater diversity of forbs $(57 \%)$ than graminoids $(36 \%)$ and shrubs/trees $\left(\chi^{2}=172.4\right.$, $\mathrm{df}=2, \mathrm{P}<0.001)$, and $35 \%$ more perennials than annuals/biennials $\left(\chi^{2}=214.3, \mathrm{df}=2, \mathrm{P}<\right.$ 0.001) (Table 2). Perennial graminoids (120) and forbs (135) were also collected more often among studies than annual/biennial graminoids (36) and forbs (93) $\left(\chi^{2}=37.8, \mathrm{df}=4, \mathrm{P}<\right.$ $0.001)$.

\section{Figure 1 near here}

\subsection{How many of these species are weeds?}

Seeds of a wide diversity of weed species have been collected on clothing, with nearly all $(87 \%)$ of the species in the database cited as weeds in some part of the world (Randall, 2012) (Supplementary material 1). Clothing can also carry the seeds of globally invasive species including many international environmental weeds (58 species) (Table 2).

At least 287 invasive or naturalized alien plants in one or more European countries (DAISIE, 2008) can be dispersed on clothing, with most (192 species) recorded from one or more of the six European studies (Table 1, Table 2). More than one-third are naturalized alien species in one or more North and Central European countries, with 38 declared as invasive (NOBANIS, 2013) (Table 2). This includes almost one-fifth of the 150 most widespread alien species in Europe (Lambdon et al., 2008) and 6\% of the alien flora of the Czech Republic (Pyšek et al., 2012). Of the 197 species recorded in a study conducted in Sweden (Auffret and Cousins, 2013), 47 are naturalized and seven declared invasive (NOBANIS, 2013). Seven of the 62 
species recorded in a study from the United Kingdom (Woodruffe-Peacock, 1918; Clifford, 1956; Wichmann et al., 2009) were also naturalized.

About $8 \%$ of the species collected on clothing are naturalised in Australia, including eight species that are classified as invasive (Randall, 2007). These include about $7 \%$ of the noxious weeds in Australia (Australian Weeds Committee, 2012a) and two Weeds of National Significance: Andropogon gayanus (Gamba grass) and Nassella neesiana (Chilean needle grass) (Australian Weeds Committee, 2012b). Of the 157 species recorded in one or more of the six Australian studies, 48\% (75) are naturalised weeds in Australia.

Although none of the studies were conducted in North America, India, China or South Africa, weeds from these regions have been found on clothing in one or more studies. For instance, at least one-tenth of the invasive/noxious species in North America (Invasive.org, 2010) were in the clothing database. Around 5\% of the species collected on clothing are also alien species in India. This includes $28 \%$ of the species classified as invasive in India (Khuroo et al., 2012) (Table 2). Also, 13\% of the 265 species listed as invasive species in China (Xu et al., 2012) have been collected from clothing. Only five species that are declared weeds or invaders in South Africa (South Africa Government Gazette, 2001) have been collected on clothing (Table 2).

\subsection{How many seeds can be dispersed from clothing and how many could be viable?}

Several studies collected large numbers of seeds from clothing, with 24,776 seeds from 70 taxa collected from different types of clothing worn in Kosciuszko National Park, Australia (Mount and Pickering, 2009), 24,354 seeds of 197 species from the clothing worn by meadows cutters in Sweden (Auffret and Cousins, 2013), 2,686 seeds from 854 visitors to the Antarctic (Chown et al., 2012), 1,019 seeds from 259 travellers to the remote Svalbard Island in the Arctic (Ware et al., 2012), 981 seeds from 64 expeditioners to a subantarctic island reserve (Whinam et al., 2005), 446 seeds from the footwear of passengers arriving by plane in New Zealand (McNeill et al., 2011) and 120 seeds of the perennial graminoid Andropogon gayanus on the clothing of just four people south of Darwin, Australia (Scott, 2009). All the studies that germinated seeds found many were viable, with 42 plants (39 species) (Clifford, 1956), 163 plants (24 species) (Whinam et al., 2005), 243 seedlings (McNeill et al., 2011), and 264 seedlings (Ware et al., 2012) germinating when samples collected from clothing were sown in glasshouses or laboratories. When seeds on visitors to the Antarctic were collected and their likelihood to establish assessed by Chown et al. (2012), roughly $47 \%$ of 
the 2,686 seeds, according to their criteria, had the potential to establish in the Antarctic environment.

By extrapolating values for individuals, some studies have provided estimates for the total amount of seeds that could be introduced into protected areas annually by visitors. For instance, the potential amount of seeds that could be introduced on clothing by hikers to the alpine area around Australia's highest mountain, Mt Kosciuszko was 1.9 million seeds if all visitors were wearing socks and 2.4 million if they were wearing trousers, although the actual numbers of seeds would be much lower as there would not be that many seeds available at the start of walks in this part of the Park (Pickering and Mount 2010). When the annual number of visitors to the Antarctic was multiplied with the average (9.5) number of seeds per visitor obtained during the International Polar Year's first season (2007-2008), it was estimated that 70,600 weed seeds could enter Antarctic each summer season (Chown et al., 2012). About 270,000 seeds per year were also estimated to be introduced by visitors flying into the remote Svalbard Archipelago in the Arctic Circle each year, when the average (3.9) seeds per visitor were multiplied by the annual number of visitors to the Island (Ware et al., 2012).

\subsection{How far can seed be dispersed by hikers?}

Seeds on clothing could be dispersed at different distances along trails including over several kilometres by hikers. When the distance seeds could be dispersed from cotton clothing worn by hikers was assessed, the average distance for the perennial forb Petiveria alliacea (Guinea henweed) was $157 \mathrm{~m}$ in a forest, and $33 \mathrm{~m}$ in a disturbed weedy roadside area (Bullock and Primack, 1977). The average dispersal distance of seeds for the forb Achyranthes aspera (Chaff flower) from trouser legs by hikers was $34 \mathrm{~m}$ in high grassy vegetation and approximately $2.5 \mathrm{~km}$ along an open trail (Bullock and Primack, 1977). In studies modelling the dispersal distance of seeds from different types of clothing, proportionally more seeds were dispersed within the first few metres of a hike than later, although the proportion of seeds dispersed varied among species. By $5 \mathrm{~m}$ it ranged from 58\% for Brassica nigra (Black mustard) to $65 \%$ for Brassica oleracea (Cabbage) for seeds on shoes (Wichmann et al., 2009). For seeds on trousers and socks, by $5 \mathrm{~m}$ it ranged from $19 \%$ for Heteropogon contortus (Black speargrass) to $80 \%$ for Festuca rubra (Red Fescue) on trousers and $16 \%$ for Heteropogon contortus to $76 \%$ for Paspalum urvillei (Vasey Grass) on socks across the 14 species compared using the same basic protocol (Pickering et al., 2011; Ansong and 
Pickering, 2013c, Ansong and Pickering, in review). By $5 \mathrm{~km}$, nearly all seeds have fallen off clothing, with values ranging from $55 \%$ to $100 \%$ from trousers, $52 \%$ to $99 \%$ on socks and 99\% to 100\% from shoes (Wichmann et al., 2009; Pickering et al., 2011; Ansong and Pickering, 2013c). Some seed can be carried even further, with an average potential dispersal distance of $13 \mathrm{~km}$ for seeds collected from the clothing of people cutting meadows in Sweden (Auffret and Cousins, 2013). Therefore, the seeds of some species can be carried long distances on hiker's clothing, but this varies among species and types of clothing (Wichmann et al., 2009; Pickering et al., 2011; Ansong and Pickering, 2013c; Auffret and Cousins, 2013).

\subsection{Are some species common among studies?}

Although 346 of the species were not recorded in more than one study, a few were more common (Supplementary material 1). Twelve species were recorded in five or more of the studies (Supplementary material 1), eight of which are classified as international environmental weeds (Weber, 2003). They are all naturalized alien species in Australia (Randall, 2007) and either invasive or noxious in North America (Invasive.org, 2010) with 11 classified as invasive/naturalized alien species in one or more of the European countries (DAISIE, 2008). All are perennial species, except Pоа аппиа (Winter Grass). Seven were graminoids, with five forbs. The four most common species were Poa annua, Anthoxanthum odoratum (Sweet Vernal Grass), Holcus lanatus (Yorkshire Fog), and Hypochaeris radicata (Catsear) which were recorded in seven or more studies.

Poa annua was the most common species and was recorded in 10 studies, mostly in Australian (five) or European (three) studies. Although not considered a global environmental weed, this small annual grass is naturalized in several countries including Australia (Randall, 2007), India (Khuroo et al., 2012), some parts of Europe (DAISIE, 2008), and it is a declared invasive in North America (Invasive.org, 2010).

The next most common species was the perennial grass Anthoxanthum odoratum, which is native to Asia, some parts of Europe, and some parts of the Atlantic Islands (Weber, 2003). It is highly competitive, with rapid growth and often flowers earlier than native species, when introduced. Anthoxanthum odoratum is a global environmental weed (Weber, 2003), and is naturalized in Australia (Randall, 2007), North America (Invasive.org, 2010), India and parts of Europe where it is not native (DAISIE, 2008). It was recorded in seven of the studies: four in Australia, two in Europe, and one from New Zealand. 
The perennial grass Holcus lanatus was recorded in seven studies: three in Australia, two in Europe and one each in New Zealand and Antarctica. This native to Europe, Northern Africa and temperate Asia, is a global environmental weed (Weber, 2003) and has become naturalized in Australia (Randall, 2007), North America (Invasive.org, 2010) and parts of Europe where it is not native (DAISIE, 2008). The grass produces large numbers of seeds and can grow in a range of different soil types. It has been found to reduce native species richness by forming dense swards (Weber, 2003).

The next most common species was the perennial forb Hypochaeris radicata. It is native to some parts of Europe, Northern Africa, some parts of Asia and the Atlantic Islands (Weber, 2003) but is considered alien in other parts of Europe, is naturalized in Australia, India, and invasive in North America (Randall, 2007; DAISIE, 2008; Invasive.org, 2010; Khuroo et al., 2012). Hypochaeris radicata seeds were collected from seven studies, five from Australia and one each from Europe and Hawaii.

\subsection{What plant and seed traits influence attachment and detachment of seeds from clothing?}

Several of the studies have found a range of plant traits influence the number of seeds attaching to clothing. This includes the number of seeds produced by plants, the position of seeds on plants relative to clothing and seed traits such as the presence or absence of attachment structures and seed size (Figure 2) (Shmida and Ellner, 1983; Mount and Pickering, 2009; Pickering et al., 2011; Ansong and Pickering, 2013c). Plants that produce more seeds often succeed in attaching more seeds to clothing than those with fewer seeds, all else being equal (Sorensen, 1986; Hovstad et al., 2009; Mount and Pickering, 2009). The height of the seeds on the plant in relation to different items of clothing also influences where, and/or on what type of clothing seeds attach (Hovstad et al., 2009). For example, seeds located 10 to $40 \mathrm{~cm}$ from the ground on plants may be more likely to attach to socks than seeds located higher off the ground. The arrangement of seeds on plants can also determine if they come into contact with clothing and hence more likely to attach to clothing (Bullock and Primack, 1977; Sorensen, 1986). For instances, seeds that are clustered and position radially such as those of the environmental weed Bidens pilosa (Cobbler's pegs) are more likely to attach to clothing compared to vertically orientated seeds such as those of Achyranthes aspera (Bullock and Primack, 1977). Seeds with adhesive structures such as long awns, hairs and hooks can also have higher attachment rates than those without these 
types of structures (Bullock and Primack, 1977; Shmida and Ellner, 1983; Mount and Pickering, 2009; Pickering et al., 2011).

\section{Figure 2 near here}

The number of seeds that become attached to clothing, the position of the seeds on the clothing, and the morphology of the seeds can all influence the detachment rates of seeds (Figure 2). The more seeds that attach, the greater the potential for some seeds to be transported over longer distances, as dispersal is often proportional to the number of seeds that attach to clothing (Shmida and Ellner, 1983; Sorensen, 1986; Mount and Pickering, 2009; Pickering et al., 2011; Ansong and Pickering, 2013c). Where seeds become attached to clothing also influences how far the seeds may be transported. Seeds lodged in pockets and in the folds or interior of shoes, for example, can be transported over longer distances than those attached to external surfaces of clothes (Scott, 2009). Seeds with long awns, hairs and hooks can remain attached to clothing over longer distances than those without these structures (Mount and Pickering, 2009; Pickering et al., 2011; Ansong and Pickering, 2013c).

\subsection{What characteristics of clothing influence attachment and detachment?}

The type of clothing, the combination of clothing worn and the behaviour of those wearing the clothing affect the amount and type of seeds that can be dispersed (Figure 2) (Mount and Pickering, 2009; Wichmann et al., 2009; Pickering et al., 2011; Ansong and Pickering, 2013c). Different numbers and diversities of seeds were found on shoes, socks and trouser legs in an experiment with uncovered socks and laces collecting significantly more seeds than covered socks and laces (Mount and Pickering, 2009). For the same type of clothing, the surface area of the item and the adhesive quality of material it is made from are also important (Bullock and Primack, 1977; Whinam et al., 2005; Mount and Pickering, 2009). More native seeds were collected, for example, on sports socks than on hiking socks (Mount and Pickering, 2009), while the cuffs and Velcro closures of outer clothing were more likely to contain and disperse seeds (Whinam et al., 2005).

The behaviour of humans such as where they walk is also important (Figure 2) (Mount and Pickering, 2009; Ware et al., 2012). Footwear used when walking through forested and alpine areas, for example, collected more seeds than the same footwear worn when walking in rural or urban areas (Ware et al., 2012). Also, when the seeds in soil removed from footwear in the luggage of international passengers arriving in New Zealand by plane were assessed, soil 
from golf shoes were found to have the largest number of seeds, with $5.2 \pm 1.16$ seeds/g of soil, compared with $2.1 \pm 0.80$ for sports shoes, $1.9 \pm 0.56$ for miscellaneous footwear, and $1.8 \pm 0.34$ for hiking boots (McNeill et al., 2011). Also, socks worn by visitors who walked off-track in protected areas collected more native seeds than weeds while those worn by visitors who walked along roadsides collected more weed seeds than native seeds (Mount and Pickering, 2009).

The surface area of the clothing, the location (such as height), the number and type of seeds attached and the adhesive quality of the clothing, can all affect seed detachment (Figure 2) (Bullock and Primack, 1977; Whinam et al., 2005; Mount and Pickering, 2009; Pickering et al., 2011; Ansong and Pickering, 2013c). For example, seeds detached sooner from trousers made of $100 \%$ drill cotton than from socks made of cotton/nylon blend (Pickering et al., 2011; Ansong and Pickering, 2013c). Seeds also detached sooner from Wellington boots made of rubber than from walking boots made of leather (Wichmann et al., 2009).

\subsection{What are the effects of environmental conditions on attachment and detachment of seeds} from clothing?

Climatic conditions such as rain affect the attachment of seeds to clothing, but effects depend on context, as wet conditions can increase or decrease attachment (Figure 2). Some seeds have structures, that when wet, become sticky or twist into clothing such the seeds of Heteropogon contortus (Ansong and Pickering, 2013c). As a result, the attachment of seeds with these structures is more likely in wetter conditions. Wet conditions could also influence the amount of seeds attaching to the bottom and sides of footwear by increasing the adhesive quality of mud/soil (Clifford, 1956). It is possible however, that in very wet conditions, seeds in soils on shoes might wash off footwear when treading in puddles, streams or rivers.

Season can also partially affect the attachment of seeds to clothing as it will affect which species are seeding. Although there appears to be limited research specifically on this aspect of seed dispersal from clothing, there is some research on the general effects of seasonality on dispersal. For example, season affected the number of seeds in soil collected from the footwear of passengers arriving in New Zealand, with seeds counts in both January and October significantly higher than those in March and April (McNeill et al., 2011).

\section{Discussion}


Seeds from a diversity of plants, many of them weeds, can be unintentionally carried and dispersed from clothing. To date, nearly all of the species recorded with seeds on clothing are weeds in some part of the world (Randall, 2012), including some that are globally invasive and internationally important environmental weeds (Weber, 2003). When dispersal distances of seeds were quantified on the clothing of hikers, seeds of some weeds were found to be carried many kilometres (Bullock and Primack, 1977; Mount and Pickering, 2009; Pickering et al., 2011; Ansong and Pickering, 2013c; Auffret and Cousins, 2013). When people travel in cars, planes, trains and boats, seeds on their clothing could however, be transported much further including between continents (Whinam et al., 2005; McNeill et al., 2011; Chown et al., 2012; Ware et al., 2012). These results highlight the importance of clothing as type of human-mediated seed dispersal.

The potential for people to spread weed seeds from their clothing is a global-scale problem. Studies from Antarctica, Asia, Australia, Europe, New Zealand and Hawaii found seeds on clothing, including visitors to protected and other remote areas. As estimated in this review, at least $43 \%$ of the Federal noxious weeds of the United States, $28 \%$ of invasive alien species in India, $13 \%$ of invasive species in China, $8 \%$ of weed species naturalized in Australia, $6 \%$ of the alien flora of the Czech Republic and 3\% of invaders in South Africa could be transported by this mechanism.

A large proportion of the seeds collected on clothing were viable when germinated in greenhouses or laboratories (Clifford, 1956; Whinam et al., 2005; McNeill et al., 2011). This indicates that seeds dispersed by this mechanism may germinate if they fall to the ground in sites when conditions are suitable. Where seeds do germinate, it is possible that some may achieve maturity and set seed, going on to establish self-perpetuating populations thereby contributing to biological invasion (McKinney and Lockwood, 1999; Olden, 2006; Lee and Chown, 2009; Chown et al., 2012; Stohlgren et al., 2013). This includes in regions that are popular but remote tourism destinations such as sub-Antarctic and Arctic Islands and other remote reserves with highly endemic floras (Csurhes and Edwards, 1998; Williams and West, 2000; Groves et al., 2005; Pyšek and Richardson, 2010).

It appears that clothing is more likely to carry the seeds of perennial forbs and graminoids, rather than their annual counterparts or the seeds of shrubs or trees. These patterns are likely to reflect the combined effects of vector (where, when they go, and what they wear) and that of the seeds/plants (where the plants grow, the number of seeds they produce, seed structures 
and where the seeds are located on the plants). This was reflected in the families with high species diversity in the database, with the Poaceae, Asteraceae, Cyperaceae, Fabaceae and Caryophyllaceae accounting for $55 \%$ of the species in the database. These families contain many species that have high seed outputs including species used by humans as food, fodder for livestock and/or as ornamental plants, which will increase the potential for seeds to attach to clothing (Weber, 2003; GRIN Taxonomy for Plants, 2012; Randall, 2012; Royal Botanic Gardens and Domain Trust, 2012). They also include many species with adhesive appendages on their seeds that are likely to aid in attachment, some of which are already known to attach to fur (Weber, 2003; GRIN Taxonomy for Plants, 2012; Randall, 2012; Royal Botanic Gardens and Domain Trust, 2012). They also contain many species of weeds that are widely distributed and adapted to different environments, where they can out-compete native species (Weber, 2003; GRIN Taxonomy for Plants, 2012; Randall, 2012; Royal Botanic Gardens and Domain Trust, 2012)

Despite almost a century of published research on seed dispersal from clothing, and increasing concern about anthropochory, there are still surprisingly few papers on this topic in the academic literature. Of even more concern are the geographical gaps in the research, with no studies found from North America, South America, Africa (except South Africa), and only one paper each from Central America and Asia (Table 1). The current review highlights the importance of additional research that: (1) quantifies the diversity and composition of seeds and species that can attach to and disperse from different types of clothing, (2) determines how the type of material clothing is made from affects the number of seeds that attach and are dispersed, and (3) quantifies the effects of seed traits such as weight, mass and appendages on how far seeds can be transported by hikers. This type of research, particularly in areas currently poorly represented in the literature, will not only increase our understanding of anthropochory, but also add new species to those known to have seeds dispersed from clothing.

\subsection{Management implications}

It is important to understand and manage different dispersal vectors for weeds, including clothing to maintain the conservation value of many protected areas.. As with other humanmediated dispersal mechanisms, the risk of introducing weed seeds on clothing should be minimized since propagule pressure is an important predictor of plant invasions (Pyšek and Richardson, 2010; McNeill et al., 2011; Pickering et al., 2011; Stohlgren et al., 2013). 
Visitors can reduce the risk that they may introduce weed seeds by washing clothing and cleaning footwear, including removing any attached soil before they enter protected areas (Mount, 2008; Scott, 2009; McNeill et al., 2011). They can also carefully dispose of any seeds that become attached to their clothing when in the area. Covering socks, not using Velcro fastenings and keeping pockets closed/zipped can all minimize the risk of seeds attaching to clothing (Whinam et al., 2005; Mount, 2008; Scott, 2009; Ansong and Pickering, 2013c). Avoiding walking through weedy areas such the edges of roads and car parks prior to starting walks could also reduce the chance of new weed seeds attaching to clothing (Mount, 2008).

This type of information could be incorporated into education programmes for visitors and others using protected areas (Powell, 1968; Whinam et al., 2005; McNeill et al., 2011; Ware et al., 2012; Ansong and Pickering, 2013c). This could include clear instructions about the proper cleaning techniques for clothing and the need to clean clothing before arriving (McNeill et al., 2011; Ware et al., 2012). This could be incorporated into information guides for visitors including minimum impact codes (Ansong and Pickering, 2013c) and visual material around entry points (Whinam et al., 2005). Also, wash down facilities that are used in many protected areas to minimise the spread of plant and frog pathogens, may also help reduce the chance of the spread of weed seeds via soil on boots. In some remote areas of particular conservation value, biosecurity officers could also help implement these education programmes, as has been recommended for expeditions to subantarctic islands (Whinam et al., 2005; Ware et al., 2012).

\section{Conclusion}

We have highlighted in this review the potential range of weed species that can be dispersed from clothing, and how this can occur. This includes starting to assess the effects of: 1) the clothing type and material, 2) the number of seeds of the plant available for attachment and their ability to come in to contact with the clothing, 3) seed traits such as adhesive and attachment structures, and 4) environmental conditions affecting seed attachment to clothing.

As seeds could remain attached to clothing until they are removed or fall off by themselves, clothing can contribute to the introduction of diverse alien species to and within many regions. In addition, as visitors tend to congregate in similar places within protected areas, seeds attached to clothing could benefit from "directed" or "targeted" dispersal. If these habitats are suitable, the seeds may germinate and grow. Although, the review did not find 
studies that have directly assessed if any of the seeds from clothing went on to establish viable populations once dispersed, the high number of weeds in the database highlights the potential threat of this type of human-mediated dispersal mechanism for biodiversity in many regions. We recommend that more research on this, and other types of unintentional humanmediated seed dispersal, be undertaken including in regions such as North America, Africa and Asia where there is limited research so this topic to date.

\section{Acknowledgements}

The authors would like to thank Ann Mount who provided us with some original data for use in the database, Mark Ballantyne and Clare Morrison for proof reading the manuscript, and the anonymous reviewers for their comments. One of the authors, Michael Ansong, would like to also acknowledge financial support from the Griffith University Postgraduate Research Scholarship Scheme.

\section{Reference}

Ansong, M., Pickering, C., 2013a. Are weeds hitchhiking a ride on your car? A systematic review of seeds dispersal on cars. PLoS One 8, e80275.

Ansong, M., Pickering, C., 2013b. A global review of weeds that can germinate from horse dung. Ecological Management and Restoration 14, 216-223.

Ansong, M., Pickering, C., 2013c. Long-distance dispersal of Black Spear Grass (Heteropogon contortus) seeds on socks and trouser legs by walkers in Kakadu National Park. Ecological Management and Restoration 14, 71-74.

Auffret, A.G., Cousins, S.A.O., 2013. Humans as long-distance dispersers of rural plant communities. PLoS One 8, e62763.

Australian Weeds Committee, 2012a. Noxious Weed List for Australian States and Territories. http://www.weeds.org.au/noxious.htm (accessed 20 December 2012).

Australian Weeds Committee, 2012b. Weeds of National Significance. http://www.weeds.org.au/WoNS (accessed 4 December 2012).

Bullock, S.H., Primack, R.B., 1977. Comparative experimental study of seeds dispersal on animals. Ecology 58, 681-686.

Chown, S.L., Huiskes, A.H., Gremmen, N.J., Lee, J.E., Terauds, A., Crosbie, K., Frenot, Y., Hughes, K.A., Imura, S., Kiefer, K., Lebouvier, M., Raymond, B., Tsujimoto, M., Ware, C., Van de Vijver, B., Bergstrom, D.M., 2012. Continent-wide risk assessment for the establishment of nonindigenous species in Antarctica. Proceedings of National Academy of Science, USA 109, 4938-4943.

Clifford, H.T., 1956. Seeds dispersal on footwear. Proceedings of the Botanical Society of the British Isles 2, 129-131.

Csurhes, S., Edwards, R., 1998. Potential Environmental Weeds in Australia: Candidate Species for Preventative Control. Environment Australia, Canberra.

Darby, A., 2012. As you sow, so shall you reap, Antarctic tourism body warns visitors. The Sydney Morning Heralds. http://www.smh.com.au/national/as-you-sow-so-shall-youreap-antarctic-tourism-body-warns-visitors-20120611-2065a.html\#ixzz2d91yIaGQ (accessed 10 October 2013). 
Delivering Alien Invasive Species Inventories for Europe (DAISIE), 2008. DAISIE European Invasive Alien Species Gateway. http://www.europealiens.org/speciesSearch.do (accessed 7 January 2013).

Director of National Parks, 2011. Parks Australia Sustainable Tourism Overview 2011-2016. Commonwealth of Australia, Canberra, Australia.

European Network on Invasive Alien Species (NOBANIS), 2013. Online Database of the European Network on Invasive Alien Species, NOBANIS. http://www.nobanis.org/Search.asp (accessed 20 May 2013).

Falinski, J.B., 1972. Anthropochory in xerothermic grasslands in the light of experimental data. ACTA Socitatis Botanicorum Poloniae 41, 357-367.

Germplasm Resources Information Network Taxonomy for Plants, 2012. USDA, ARS, National Genetic Resources Program. Germplasm Resources Information NetworkOnline Database, National Germplasm Resources Laboratory. http://www.arsgrin.gov/cgi-bin/npgs/html/taxgenform.pl (accessed 7 January 2013).

Groves, R.H., Lonsdale, M., Boden, R., 2005. Jumping the Garden Fence: Invasive Garden Plants in Australia and their Environmental and Agricultural Impacts. CSIRO Report Prepared for WWF-Australia.

http://www.weeds.org.au/docs/jumping_the_garden_fence.pdf (accessed 10 November 2012).

Healy, A.J., 1943. Seeds dispersal by human activity. Nature 151, 140-140.

Higashino, P.K., Guyer, W., Stone, C.P., 1983. The Kilauea wilderness marathon and crater rim runs: sole searching experiences. Hawaiian Botanical Society 22, 25-28.

Hovstad, K.A., Borvik, S., Ohlson, M., 2009. Epizoochorous seeds dispersal in relation to seeds availability - an experiment with a red fox dummy. Journal of Vegetation Science 20, 455-464.

Hulme, P.E., Roy, D.B., Cunha, T., Larsson, T.B., 2009. A pan-European inventory of alien species: rationale, implementation and implications for managing biological invasions, In: DAISIE (Ed.), The Handbook of Alien Species in Europe. Springer, Dordrecht, pp. 1-14.

International Association of Antarctica Tour Operators, 2013. Report of the International Association of Antarctica Tour Operators-2012/13. http://iaato.org/current-iaatoinformation-papers (accessed 18 September 2013).

Invasive.org, 2010. Invasive and Exotic Plants. http://www.invasive.org (accessed 3 January 2013).

Johnston, F.M., Pickering, C.M., 2001. Alien plants in the Australian Alps. Mountain Research and Development 21, 284-291.

Khuroo, A.A., Reshi, Z.A., Malik, A.H., Weber, E., Rashid, I., Dar, G., 2012. Alien flora of India: taxonomic composition, invasion status and biogeographic affiliations. Biological Invasions 14, 99-113.

Lambdon, P.W., Pyšek, P., Basnou, C., Hejda, M., Arianoutsou, M., Essl, F., Jarošík, V., Pergl, J., Winter, M., Anastasiu, P., 2008. Alien flora of Europe: species diversity, temporal trends, geographical patterns and research needs. Preslia 80, 101-149.

Lee, J.E., Chown, S.L., 2009. Breaching the dispersal barrier to invasion: quantification and management. Ecological Applications 19, 1944-1959.

McDougall, K.L., Khuroo, A.A., Loope, L.L., Parks, C.G., Pauchard, A., Reshi, Z.A., Rushworth, I., Kueffer, C., 2011. Plant invasions in mountains: global lessons for better management. Mountain Research and Development 31, 380-387.

McKinney, M.L., Lockwood, J.L., 1999. Biotic homogenization: a few winners replacing many losers in the next mass extinction. Trends in Ecology and Evolution 14, 450-453. 
McNeill, M., Phillips, C., Young, S., Shah, F., Aalders, L., Bell, N., Gerard, E., Littlejohn, R., 2011. Transportation of nonindigenous species via soil on international aircraft passengers' footwear. Biological Invasions 13, 2799-2815.

Mount, A., 2008. Humans as Seeds Vectors: Quantifying Seeds Collected on Different Items of Clothing when Walking in Kosciuszko National Park, Australia, School of Environment. Griffith University, Australia, Gold Coast, Australia.

Mount, A., Pickering, C.M., 2009. Testing the capacity of clothing to act as a vector for nonnative seeds in protected areas. Journal of Environmental Management 91, 168-179.

Newsome, D., Moore, S., Dowling, R., 2012. Natural Area Tourism: Ecology, Impacts and Management. Channel View Publications, Sydney.

Olden, J.D., 2006. Biotic homogenization: a new research agenda for conservation biogeography. Journal of Biogeography 33, 2027-2039.

Pauchard, A., Kueffer, C., Dietz, H., Daehler, C.C., Alexander, J., Edwards, P.J., Arévalo, J.R., Cavieres, L.A., Guisan, A., Haider, S., Jakobs, G., McDougall, K., Millar, C.I., Naylor, B.J., Parks, C.G., Rew, L.J., Seipel, T., 2009. Ain't no mountain high enough: plant invasions reaching new elevations. Frontiers in Ecology and the Environment 7, 479-486.

Pickering, C., Hill, W., 2007. Roadside weeds of the Snowy Mountains, Australia. Mountain Research and Development 27, 359-367.

Pickering, C.M., Mount, A., 2010. Do tourists disperse weed seeds? A global review of unintentional human-mediated terrestrial seeds dispersal on clothing, vehicles and horses. Journal of Sustainable Tourism 18, 239-256.

Pickering, C.M., Mount, A., Wichmann, M.C., Bullock, J.M., 2011. Estimating humanmediated dispersal of seedss within an Australian protected area. Biological Invasions 13, 1869-1880.

Powell, R.H., 1968. Harmful plant species entering New Zealand 1963-1967. New Zealand Journal of Botany 6, 395-401.

Pyšek, P., Danihelka, J., Sádlo, J., Chrtek Jr, J., Chytrý, M., Jarošík, V., Kaplan, Z., Krahulec, F., 2012. Catalogue of alien plants of the Czech Republic: checklist update, taxonomic diversity and invasion patterns. Preslia 84, 155-255.

Pyšek, P., Richardson, D.M., 2010. Invasive species, environmental change and management, and health. Annual Review of Environment and Resources 35, 25-55.

Randall, R.P., 2007. The Introduced Flora of Australia and its Weed Status. Coopreative Research Centre for Australian Weed Management, Perth, Australia.

Randall, R.P., 2012. A Global Compendium of Weeds, Second edn. Department of Agriculture and Food, Western Australia, Perth, Australia.

Royal Botanic Gardens and Domain Trust, 2012. PlantNET-The Plant Information Network System of The Royal Botanic Gardens and Domain Trust, version 2. http://plantnet.rbgsyd.nsw.gov.au/ (accessed 7 January 2013).

Scott, K.A., 2009. Potential for the dispersal of weed seedss on clothing: an example with Gamba Grass in northern Australia. Ecological Management and Restoration 10, 71-73.

Shmida, A., Ellner, S., 1983. Seeds dispersal on pastoral grazers in open Mediterranean chaparral, Israel. Israel Journal of Botany 32, 147-159.

Sinden, J., Jones, R., Hester, S., Odom, D., Kalisch, C., James, R., Cacho, O., Griffith, G., 2004. The Economic Impact of Weeds in Australia, Coopreative Research Centre for Australian Weed Management.

file:///C:/Users/s2831332/Downloads/3deec52dc8d1566048.pdf (accessed 20 August 2012).

Sorensen, A.E., 1986. Seeds dispersal by adhesion. Annual Review of Ecology and Systematics 17, 443-463. 
South Africa Government Gazette, 2001. Amendments to the Conservation of Agricultural Resources Act, 1983 (Act No. 43 of 1983), Department of Agriculture.

http://www.enviroleg.co.za/acts/Conservation\%20of\%20Agricultural\%20Resources/Cons ervation\%20of\%20Agricultural\%20Resources\%20Act.pdf (accessed 6 January 2013).

South African National Parks, 2013. South African National Parks Annual Report2012/2013. http://www.sanparks.org/assets/docs/general/annual-report-2013.pdf (accessed 18 September 2013).

Stohlgren, T.J., Pyšek, P., Kartesz, J., Nishino, M., Pauchard, A., Winter, M., Pino, J., Richardson, D.M., Wilson, J., Murray, B.R., Phillips, M.L., Celesti-Grapow, L., Graham, J., 2013. Globalization effects on common plant species, In: Levin, S.A. (Ed.),

Encyclopedia of Biodiversity, Second edn. Academic Press, Massachusetts, pp. 700-706.

Street, B., 2013. Statistical Abstract 2012: Natural Resource Data Series NPS/NRSS/EQD/NRDS—2013/473. National Park Service, Fort Collins, Colorado.

Taylor, K., Brummer, T., Taper, M.L., Wing, A., Rew, L.J., 2012. Human-mediated longdistance dispersal: an empirical evaluation of seeds dispersal by vehicles. Diversity and Distributions 18, 942-951.

USDA, 2013. Federal Noxious Weeds. http://plants.usda.gov/java/noxious (accessed 7 January 2013).

Vilà, M., Espinar, J.L., Hejda, M., Hulme, P.E., Jarošík, V., Maron, J.L., Pergl, J., Schaffner, U., Sun, Y., Pyšek, P., 2011. Ecological impacts of invasive alien plants: a meta-analysis of their effects on species, communities and ecosystems. Ecology Letters 14, 702-708.

Wace, N., 1985. Australia - the isolated continent., In: Gibbs, A.J., Meischke, H.R.C. (Eds.), Pests and Parasites as Migrants: An Australian Perspective. Australian Academy of Sciences, Canberra, pp. 3-22.

Ware, C., Bergstrom, D.M., Müller, E., Alsos, I.G., 2012. Humans introduce viable seedss to the Arctic on footwear. Biological Invasions 14, 567-577.

Weber, E., 2003. Invasive Plant Species of the World: A Reference Guide to Environmental Weeds. CABI, London.

Whinam, J., Chilcott, N., Bergstrom, D.M., 2005. Subantarctic hitchhikers: expeditioners as vectors for the introduction of alien organisms. Biological Conservation 121, 207-219.

Wichmann, M.C., Alexander, M.J., Soons, M.B., Galsworthy, S., Dunne, L., Gould, R., Fairfax, C., Niggemann, M., Hails, R.S., Bullock, J.M., 2009. Human-mediated dispersal of seedss over long distances. Proceedings of the Royal Society B 276, 523-532.

Williams, F., Eschen, R., Harris, A., Djeddour, D., Pratt, C., Shaw, R., Varia, S., Lamontagne-Godwin, J., Thomas, S., Murphy, S., 2010. The Economic Cost of Invasive Non-native Species on Great Britain. CABI, London.

Williams, J.A., West, C.J., 2000. Environmental weeds in Australia and New Zealand: issues and approaches to management. Austral Ecology 25, 425-444.

Woodruffe-Peacock, E.A., 1918. A fox-covert study. Journal of Ecology 6, 110-125.

Worboys, G., DeLacy, T., Lockwood, M., 2005. Protected Area Management: Principles and Practice, Second edn. Cambridge University Press, Cambridge.

Xu, H., Qiang, S., Genovesi, P., Ding, H., Wu, J., Meng, L., Han, Z., Miao, J., Hu, B., Guo, J., 2012. An inventory of invasive alien species in China. NeoBiota 15, 1-26.Figure Legend 


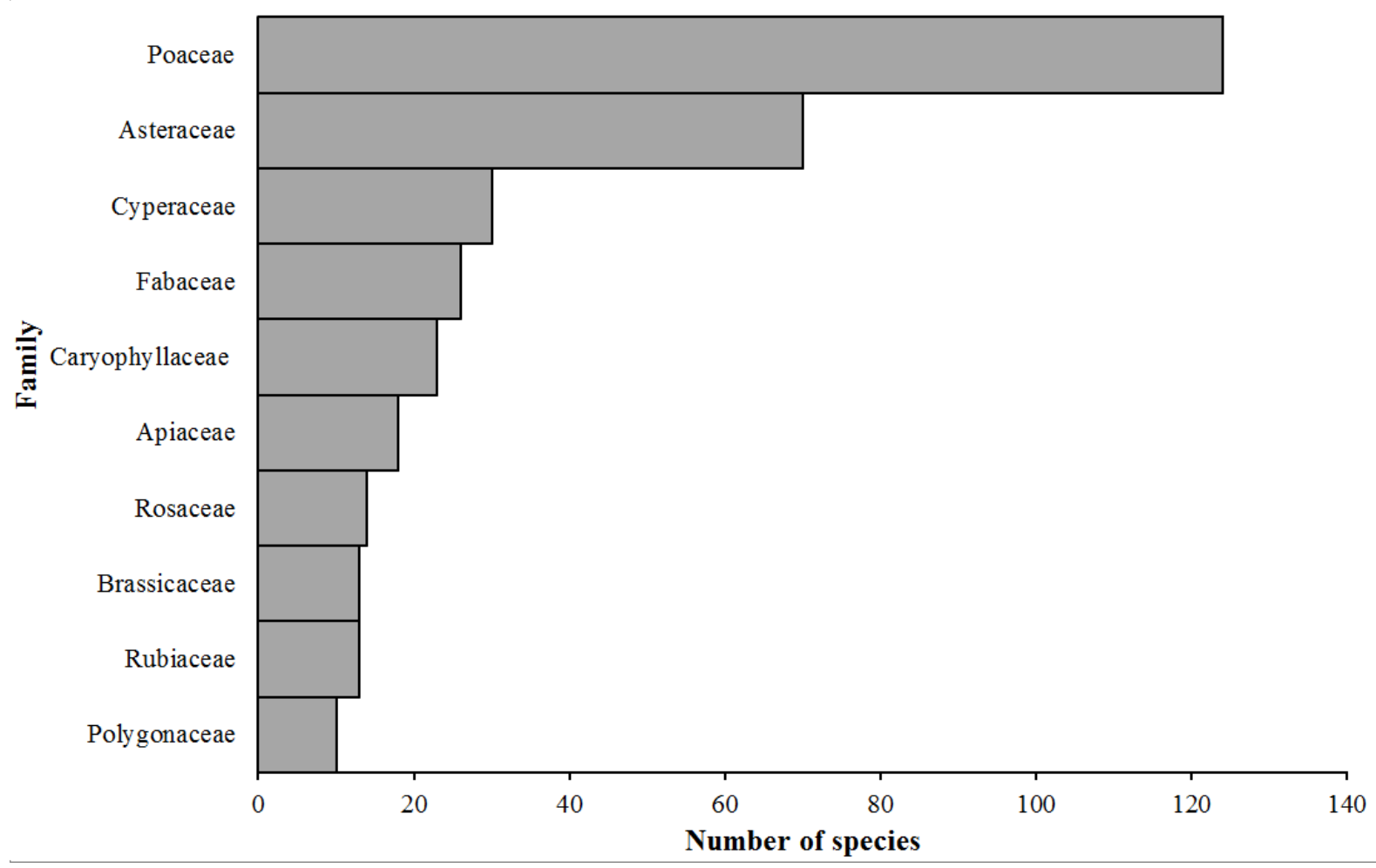

Figure 1. The number of species for plant families with seeds collected from the 21 studies that looked at seeds dispersed on clothing. The families presented in the figure had 10 or more of their species recorded. Forty-seven (47) families had less than 10 of their species recorded and hence are not included in the figure. 


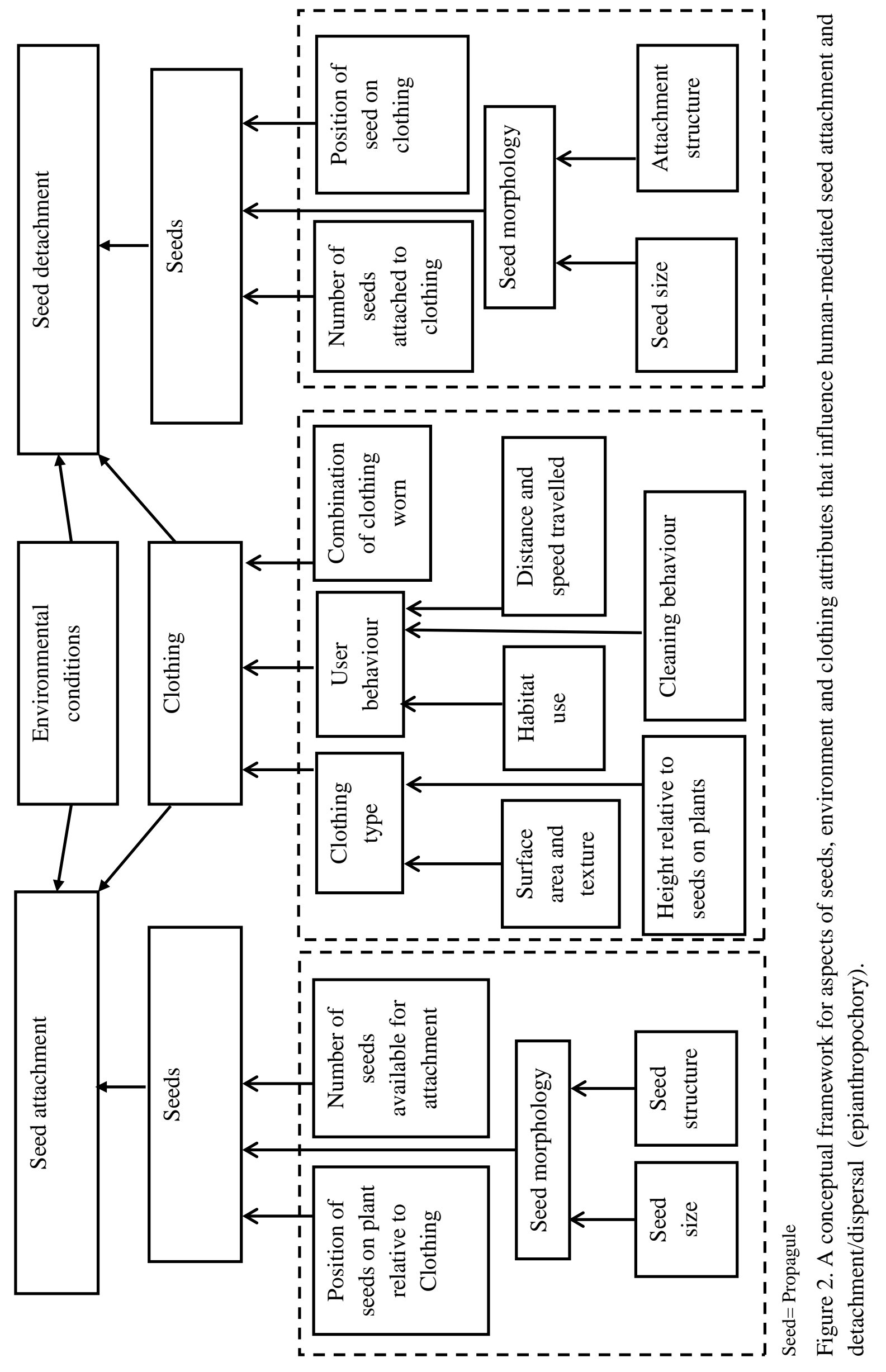




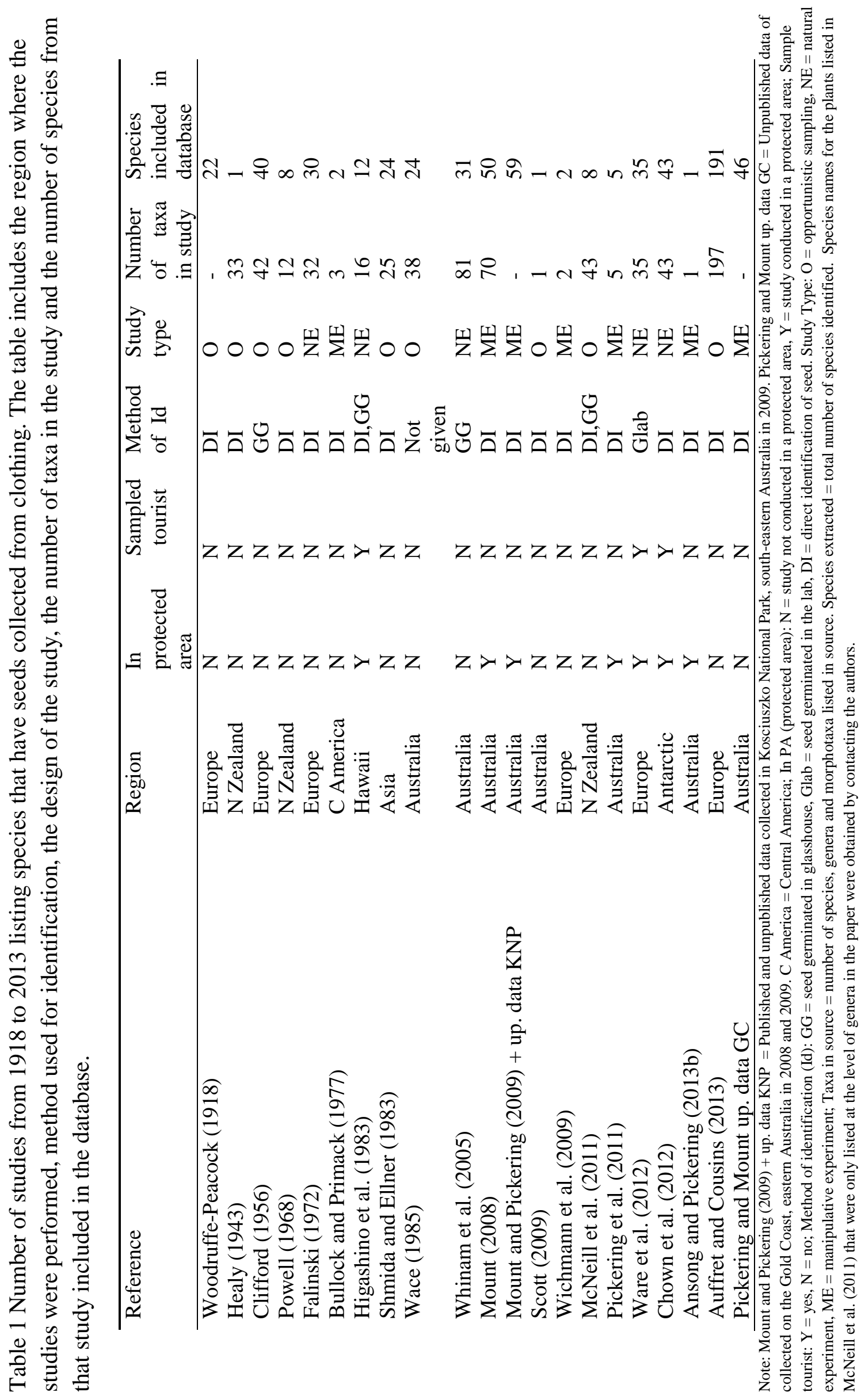


Table 2 Summary of the number of species with seeds collected from clothing, their life forms, growth forms and weed status globally, in Europe, Australia, North America, China, India and South Africa.

\begin{tabular}{|c|c|}
\hline Characteristics of the species & $\begin{array}{c}\text { Number } \\
\text { of Species }\end{array}$ \\
\hline Number of studies & 21 \\
\hline Total species & 449 \\
\hline \multicolumn{2}{|l|}{ Growth form } \\
\hline Graminoids & 163 \\
\hline Forbs & 256 \\
\hline Tree & 9 \\
\hline Shrubs & 21 \\
\hline \multicolumn{2}{|l|}{ Life span } \\
\hline Annual/biennial & 130 \\
\hline Mixed & 34 \\
\hline Perennial & 285 \\
\hline \multicolumn{2}{|l|}{ Weed status globally } \\
\hline Weed & 391 \\
\hline Environmental weed & 58 \\
\hline \multicolumn{2}{|l|}{ Weed status in Europe } \\
\hline Declared weed species & 287 \\
\hline 150 most widely naturalized species & 19 \\
\hline Invasive in Europe & 38 \\
\hline Declared weed in Czech Republic & 85 \\
\hline Invasive in Czech Republic & 5 \\
\hline \multicolumn{2}{|l|}{ Weed status in North America } \\
\hline Listed as invasive/noxious weed in North America & 156 \\
\hline Declared noxious in USA & 5 \\
\hline \multicolumn{2}{|l|}{ Weed status in Australia } \\
\hline Naturalized & 211 \\
\hline Declared invasive & 7 \\
\hline Weed of National Significance & 2 \\
\hline Declared noxious & 28 \\
\hline \multicolumn{2}{|l|}{ Weed status in India } \\
\hline Declared weed & 79 \\
\hline Declared invasive & 29 \\
\hline Declared invasive in China & 33 \\
\hline Declared invasive in South Africa & 5 \\
\hline
\end{tabular}

Note: Growth form and life span for species were obtained from the Royal Botanic Gardens and Domain Trust (2012), and GRIN Taxonomy for Plants (2012). The term mixed was used for those species that are biennial/perennial or annual/perennial. Weed status globally was according to Randall (2012) while a species was considered a global environmental weed if listed in Weber (2003). Weed in some part of Europe was based on the DAISIE database (DAISIE, 2008), invasive in Europe was according to NOBANIS, among the 150 most widespread alien species in Europe was based on Lambdon et al. (2008) while invasive in Czech Republic was based on Pyšek et al. (2012). Invasive/noxious in North America was according to Invasive.org (2010). Naturalize in Australia was according to Randall (2007), while noxious or a 'Weed of National Significance' was according to the Australian Weeds Committee (2012a, b). Weed status in India was according to Khuroo et al. (2012), while invasive weed in China was according to Xu et al. (2012), and invasive in South Africa was according to the South Africa Government Gazette (2001). 


\section{Supplementary Materials}

Supplementary 1 List of 449 species identified by the 21 studies that looked at seeds dispersed on clothing. 